\title{
A betegség- és kezelésdokumentáló szövegek közösségivé válása az újmédiában
}

\author{
ZELENA ANDRÁS \\ Budapesti Gazdasági Egyetem, Társadalomtudományi Intézet, Budapest
}

(Beérkezett: 2018. január 5.; elfogadva: 2018. december 13.)

Elméleti háttér: Napjainkban egyre nagyobb hangsúly helyeződik az élet legkülönfélébb eseményeinek közlésére és megosztására az újmédia (web2.0) felületein. E felület lehet a szociális média, a fájl- vagy videómegosztó-oldalak valamelyike, vagy blog. Tanulmányom fókuszába a betegség- és kezelésdokumentáló írásokat emelem, és kiemelt figyelmet fordítok a narratológia és a közösségi feldolgozás lehetőségdimenzióinak bemutatására. A lélektan és kommunikációtudomány interdiszciplináris elméleti bázisának továbbgondolásával e komplex kérdéskör elemzését végzem el. Cél: A kommunikáció és veszteségközzététel hagyományos rítusainak, valamint az újmédia (különös tekintettel a szociális média) felületein megjelenő betegségnapló közzétételének egymáshoz illeszthetôségét vizsgálom. Megválaszolandó kérdésem, hogy a betegségnaplókból mi épül be az újmédia keretrendszerébe, s hogyan alakulnak az interperszonális kapcsolatok, milyen szupportív gesztusokra számíthat a betegségnaplóját blogformában nyilvánossá tévő személy? Módszer: Mélyinterjúkat és dinamikus-nondirektív interjúkat vettem fel a blogírók jelentős részével kórházi osztályon, több adatközlóvel pedig strukturált interjút (otthoni, rehabilitációs tartózkodása idején) vettem fel $(n$ szumma $=27)$. Adatközlőim szocioökonómia státusza: arányos női-férfi megoszlás (14 nő, 13 férfi), 8 befejezett általános iskolától a MA/MSC szintig minden edukáltságú adatközlő megjelent, jellemzően főváros vagy főváros környéki lakhellyel rendelkeztek, és onkológiai betegséggel kezelték őket). Az általam „egyszerú véletlen mintavétellel” tüzetesebb elemzésre kiválasztott naplószövegek szerkesztettségét is vizsgálom grammatikai és szemantikai szempontból is. Eredmények: Az újmédiában való nyilvánossá tétel segítségével a lehetséges támogató gesztusokat, továbbá a terápiás írás lehetőségeit mutatom be, s a mindezt nemzetközi teoretikusok munkájával vetem össze. Úgy találtam, hogy a visszacsatolások (reagálások, kommentek, különböző emotikonokkal való válaszadás) révén a betegségélmény közösségi élménnyé válik, feltételezhető a közösségi együttérzés, támogatás jelenléte. Az újmédia színterein megjelenő közlések segítik az egyéni feldolgozást. Következtetések: A cikkben vázolt folyamatok szintetizálása és értelmezése a pszichológia- és kommunikációtudomány vonatkozó elméleteinek, valamint az új hazai és a nemzetközi kutatások eredményeinek fényében további összevetési lehetőségeket kínál. A terápiás naplóírás a blogger előnyére válik, és ez a folyamat további elemzésre érdemes.

Kulcsszavak: veszteségközzététel, betegségnapló, újmédia, web2.0

\footnotetext{
* Levelezési cím: dr. Zelena András, Budapesti Gazdasági Egyetem, KKK Társadalomtudományi Intézet, 1065 Budapest, Diósy Lajos u. 22-24. E-mail: dr.zelenaa@gmail.com
} 


\section{Bevezetés}

Tanulmányom fókuszába a betegség- és kezelésdokumentáló írásokat emelem. E komplex kérdéskört szaktudományos megállapítások szintézisével mutatom be, a lélektan, a kommunikációtudomány és a narratológia interdiszciplináris elméleti bázisának továbbgondolásával. A blogokon és a Facebook-bejegyzésekben megjelenő betegség- és kezelésdokumentálást vizsgálom, mivel az újmédia (web2.0) használói egyre nyíltabban engednek betekintést ismerőseiknek - sőt ismeretleneknek is - életük minden egyes pillanatába. A rendelkezésre álló magyar nyelvú példatár igen nagy elemszámú. Számos blog és szociális média felületen közzétett bejegyzés tartalmazza írójának betegség- és kezelésleírását. Kutatói érdeklődésem homlokterébe a nyilvánosság számára is közzétett, nem zárt csatornán hozzáférhető internetes betegségnaplók kerültek.

A vonatkozó szakcikkek és tanulmányok mind ékes bizonyítékai annak, hogy a szakkutatás élénken érdeklődik a web2.0 kitüntetett szerepe iránt. A nemzetközi tudománymetriában Q1 kvadránsba sorolt Science szaklapban Berners-Lee és munkatársai (2006) jegyzik azt az alapkutatást, amelyben a közösségi szerveződésú, azaz nem csak tartalomközzétevő, hanem tartalomfeltöltésre, megosztásra is lehetővé teremtő webes tartalmakra már web2.0-ként hivatkoznak. Lehetőség van tehát a betegség kezelése közbeni, azaz sokszor izolált kórházi környezetben megírt szövegek megosztására és közösségivé tételére, éppen ezért hangsúlyozom a - web2.0 múködési elve és hozzáférhetősége következtében - az ismerősökkel és ismeretlenekkel való megosztás sokszínúségét. Közel ezer tudományos hivatkozást váltott ki Ajjan és Hartshorne (2008) tanulmánya is, amelyben a web2.0 oktatási alkalmazhatóságát vizsgálták empirikus módon.

Jómagam Esterházy Péter (2016) kötetével vezetem be a betegségdokumentáló naplóbejegyzések vizsgálatát. Hipotézisem szerint a betegség(elôrehaladási) naplóban közzétett tartalmak és az azok által kiváltott élmények közösségivé válnak. Ennek hatását abban látom, hogy a napi akár százas nagyságrendet is elérő (hogylét felől érdeklődő kérdések), és különböző elektronikus platformon érkező érdeklődő üzenetek helyett egyöntetú, a beteg időbeosztásához illeszkedő válasz adható a barátok, ismerősök kérdéseire.

A betegségnaplók elemzésének segítségével arra a kérdésre keresem a választ, hogy milyen módon válik az újmédia (web2.0) a közösségi közzététel szinterévé? Kutatásom fontos pillérének tekintem a közösségi feldolgozás vizsgálatát is, amelyet korábbi tanulmányaimra utalva (Zelena, 2017a, 2017b), a teljesség igénye nélkül röviden összefoglalok. Írásom interdiszciplináris, a szakirodalom review-jellegú szintézise. A kommunikációelméleti és narratológiai megközelítésekhez szervesen kapcsolódik a pszichológiai 
kutatások azon része, amely az individuális élmények és traumák közösségivé alakulását, egyéniből közösségi élménnyé transzformálódását elemzi.

\section{A betegségnapló kultúrtörténete és tudományos helye}

A betegségnaplók vizsgálatakor a terápiás szövegalkotást (Buzzi, Buzzi, \& Leporini, 2010) vélelmezem. Meglátásom, hogy az írásokban a kórházi tartózkodás következtében kialakuló elszigetelődésérzés és elhatalmasodó magány irodalomterápiás szupportív gesztusa észlelhető. Egy betegség hírének befogadása komoly traumatikus életesemény, ezért a trauma reprezentációjával kapcsolatban hagyományosan a narratív feldolgozás helyeződik előtérbe. A verbalitásközpontúságból következik, hogy „a pszichoanalizis terápiás folyamata felfogható narratív interakciónak, melynek során a páciens önéletrajzi történetei, más szóval szelfnarratívumai a terapeutával együttesen alakított folyamatban módosulnak, illetve konstruálódnak" (Berán \& Unoka, 2012, 15. o.). A klasszikus kommunikációelméleti alapfogalomként használt adóvevő fogalompárt (Buda, 1988) kiterjesztem a klasszikus, nyomtatott betegségnaplók és hasonló témájú blogok és szociálismédia-bejegyzések korpuszán a szövegalkotó és olvasó-befogadó fogalompárra. Majd ezt a web2.0 csatornáján eljuttatott üzenetet helyezem a fenti kontextusba. A betegségnaplók elemzésekor elengedhetetlen e narratív interakciók szövegalkotó és befogadó kapcsolataként való értelmezése. A szövegalkotás a terápia részévé válik az adó esetében, hiszen szupportív gesztus irányul felé a vevők részéről. A vevő pedig a befogadás aktusaként bevonódik az egyéni traumába, és olvasója-értelmezője, közösségi feldolgozója lesz az egyéni életeseményeknek. Fontos adalék ehhez, a tapasztalatait terápiás praxisból merító Hamkins, aki a humanisztikus orvostudomány homlokterébe helyezi a narratív pszichiátria eszközkészletét. Vélekedése szerint e módszerrel új dimenziók nyílnak meg az orvostudomány általa múvelt szakterületén, s a narratívákat létrehozó páciens mentális betegségéből a gyógyulás útjára léphet (Hamkins, 2013).

Véleményem szerint a szépirodalmi szövegek a blogok elózményeinek is tekinthetők. Eckermann (1989) Beszélgetések Goethével, és Babits Beszélgetöfüzetei (Varga, 2014) előlegezik meg a XXI. századi veszteségkommunikációnak kevesek által ismert, ún. betegség- vagy kezelésdokumentáló formáit. A közelmúltból is találunk szomorú példát: „Mégiscsak könyv lesz ezekből a füzetekből", írja Esterházy Péter (2016, 238. o.). Az Európa-szerte ismert író betegségének stádiumait, "Hasnyálka” miatt átstrukturálódó életének szokatlanul megváltozott mindennapjait vetette papírra. Tette mindezt saját használatra dokumentáltan, kétségeivel és kiútkeresésével harcot vívva. Egy küzdelmi napló született Hasnyálkával és az íróval a főszerepben. 
Kézzel írott naplóbejegyzés a kórház felé tartó taxiban, a "höre vártan" a folyosón, az őszi napsütésben a kórház kerti padján, a fémes szájíz miatti hajnali ébredés után. Bár szerkesztett a szöveg, de marad benne írás nélkül eltelt nap utáni lelkiismeretfurdalás a "Miért nem írtam tegnap semmit se?" kérdéssel, a "bünöztem a vacsoránál, úgysem tudja senki" mondatokkal és számos személyes, ki nem mondott és családi körben el-elejtett félszavakkal, intim vallomással, ôszinte esemény- és gondolatleírással. Napló és szépirodalmi mú határmezsgyéjéról van szó. Mi más lenne egy íróember betegségdokumentációja, amiben ott a harag, az apátia, a humor, s betegségének abszurd megszemélyesítése kissé groteszkbe hajlóan, a rákkal való szokatlan (ön)dialógussal?! „83,4 kg vagyok, lettem, ez $10 \mathrm{~kg}$ mínusz karácsony óta. Rák nélkül szupi volna." - írja 2015. június 21-én vasárnap (Esterházy, 2016, 28. o.). Számos posztmodern szöveg nyers, már-már vulgáris szóhasználatával akar aktuális és szerethető lenni. Esterházy szövegében nem céltalan a trágár szóalakok alkalmazása, hanem a betegségével szüntelen harcban álló ember dühének manifesztuma. A kórral küzdő, hétköznapi beszélők szóhasználatára is a katonai metaforák jellemzők: megküzdeni a kórral, legyőzni a betegséget, harcolni a rákkal. Esterházy megszemélyesíti hasnyálmirigyrákját. Néha beszél hozzá, kér tóle; olykor áldoz neki a szavak oltárán, mintha tisztelné. A társadalmi tabuként kezelt kórról megrázó őszinteséggel vall. Az élet és a halál, a rák és örökké szavak keretezik a kötetet, ahogy Esterházy (2016, 238. o.) írja: "Az elég jó utolsó mondat volna, hogy a mindiget javítom örökkére."

\section{Internet, újmédia elméleti megközelítésben}

A nyomtatott tartalmakat követő internetes lineáris csatornák új horizontot nyitottak az információáramlásban. A 2001. szeptember 11-i terrorcselekmények túlélői internetkapcsolat birtokában, de mobilhálózat nélkül a blogokon kértek segítséget a rájuk hullott épülettörmelékek alól. Ennek segítségével adták meg pontos helyüket a mentésben résztvevők számára. Ma már ingyenes szolgáltatók tucatjai közül válogathatunk a hazai blogszolgáltatást nyújtók között, a lehetőségek tárháza igen gazdag. A blogok lineáris struktúrájához képest az újmédia (kiváltképp a szociális média) felületein lehetőség van a társak közötti visszacsatolásra és válaszreakció(k)ra is, így elmosódik a határ a személyes és a nyilvános kommunikáció, valamint a tömeg- és interperszonális kommunikáció között (McQuail, 2003). Új médiahasználati szabályrendszer hódít teret a felhasználók között, új kompetenciák elsajátítására van szüksége az internetezőknek. Egyszerre kell múvelniük a befogadás és az értelmezés kognitív folyamatait. „Elengedhetetlenné válik a technológiai-informatikai nyelv ismerete és az új kommunikációs kultúra jeleiben és protokolljában való jártasság" (Aczél, 2015, 143. o.). 
Az interperszonális kapcsolatok múködési rendjében és azok minőségében új folyamatok jelennek meg (Jenkins, Ford, \& Green, 2013). Az újmédiában az információ nemcsak kibocsátás, hanem együttes létrehozás eredménye is. Az újmédia tehát nem szórja, hanem körözteti az információt (Jenkins és mtsai, 2013), és a klasszikus tartalmak mellett egyre nagyobb teret hódít a felhasználók által létrehozott, ún. UGC-tartalom (user generated contents). Az internetezók professzionális technikai eszközökkel gyártják a tartalmakat, így mindenkinek lehetősége van narratívák alakítására. „Az újmédiát a média korábbi formáitól a digitalizáció, az interaktivitás, a hipertextualitás, a szórtság és a virtualitás - mint kulcsjellemzók - különböztetik meg" (Aczél, 2015, 147. o.). Mit is jelent pl. az interaktivitás és a hipertextualitás az újmédia színterein megjelenő betegségnaplókban? Az interaktivitás nem jelent mást, mint hogy a klasszikus közlésformákat kiegészítvén megjelenik az ismerősi körrel való azonnali megosztás lehetősége, és a perceken belüli válaszreakciók sokaságának esélye (Zelena, 2017a). A digitális világ hipertextualitása pedig hangsúlyozza az eredeti szöveg és a kommentár, válaszszöveggel (metaszöveg) való együttes jelenlétét. A válasz pedig újraközölhetősége - ún. „másolhatósága” - révén elszakítja a szövegeket szerzőjüktől (Barthes, 1996; Szúts, 2011).

\section{Betegség- és kezelésdokumentáló blogok}

A blogot író korosztály életmódjellemzői közül az információmegosztás gyorsaságát, a fiatalok hitelességre való igényét (hiszen a betegséget átélő blogot írótól hiteles információt várunk), és a tömegmédia kontrolltényezőinek fontosságát helyezte előtérbe a szociológus-ifjúságkutató Jancsák Csaba (Jancsák, 2013). A narratív történetformák szociológiai értelmezését Pászka Imre végezte el (Pászka, 2006; Pászka 2007) összefoglaló munkáiban. Vélekedése szerint, cél az élmény nyelvi megjelentetése, artikulációja. Összegzésként elmondható, hogy az élményalapú narráció (esetünkben a saját betegség- és kezelésdokumentáló internetes szövegalkotás) az ifjúság szempontjából hitelesnek tekinthetó információközlés. A hazai megállapításokat kiegészíti Bradley Lewis teóriája: a New York University professzora a pszichiátria narratív fordulataként a pszichiáter szakorvost moderátorként szerepelteti a kétirányú kommunikációs folyamatban, aki azonosítja a modelleket és a sémákat a beteg narrációjában, majd azokat a kulturális narratívákba emelten értelmezi (Lewis, 2011). 


\section{Módszer}

Az általam „egyszerú véletlen mintavétellel” tüzetesebb elemzésre kiválasztott naplószövegek szerkesztettségét is vizsgálni kívántam grammatikai és szemantikai szempontból is. Eközben kiterjesztettem a narratív elméletek kutatási fókuszát a betegség- és kezelésdokumentáció fogalomkörének szinonimáira (úgymint: betegségnapló, kezeléstörténet, kórházi napló, s e szavak különböző, akár nyelvtanilag helytelen variációira) indított kereséssel az egyik legnagyobb keresőoldal ${ }^{1}$ segítségével.

Azt állapítottam meg, hogy az előbb felsorolt keresőszavakhoz nagyjából azonos elemszámú halmaz tartozik. A kutatás ezen szakasza előre tervezetten 30 napig tartott. Az elemszáma 320 és 580 közötti, azonban rögzítenem kell, hogy ez az elemszám a kutatás 30 napja alatt gyújtött példaanyagból származik, a kutatás egy későbbi lépésekor ugyanazon keresőszavakra és ugyanazzal a keresőoldallal magasabb elemszámot találtam. A kutatás első szakaszában tehát csak a blogokat elemeztem, majd „egyszerú véletlen mintavétellel" kiválasztottam 7 blogot, és megpróbáltam felkeresni a blogot író személyt abból a célból, hogy mélyinterjút vehessek fel vele. Az egyszerú véletlen mintavételi eljárással kiválasztott bloggerek közül szinte mindenkit sikerült elérnem, egy személy vélhetően elhunyt, ugyanis utóbbi blognál a naplóbejegyzések elvágólag szúntek meg, a facebook-profil emlékoldallá alakítása megtörtént. Elutasító választ nem kaptam.

Mélyinterjúkat és dinamikus-nondirektív interjúkat vettem fel a blogírók jelentős részével kórházi osztályon $(n=17), 10$ adatközlővel pedig strukturált interjút (otthoni, rehabilitációs tartózkodása idején) vettem fel ( $n$ szumma $=27$ ). Adatközlőim szocioökonómia státusza: arányos női-férfi megoszlás (14 nő, 13 férfi), 8 befejezett általános iskolától a MA/MSC szintig minden edukáltságú adatközlő megjelent, jellemzően főváros vagy főváros környéki lakhellyel rendelkeztek, és onkológiai betegséggel kezelték óket). A helsinki és tokiói egyezmény figyelembevételével anonimizálást végeztem, és törekedtem a beazonosíthatóság elkerülésére. A kutatásetikai engedélyt a BGE KKK Társadalomtudományi Intézetének Kommunikáció Tanszéke adta ki.

\section{Eredmények}

Az újmédiában való nyilvánossá tétel segítségével a lehetséges támogató gesztusokat, továbbá a terápiás írás lehetőségeit mutatom be. Úgy találtam, hogy a visszacsatolások (reagálások, kommentek, különböző emotikonok-

1 A legnagyobb hazai fájlmegosztó oldalon indított magyar nyelvú kereséssel (youtube.com). 
kal való válaszadás) révén a betegség élménye közösségi élménnyé válik, feltételezhető a közösségi együttérzés, támogatás jelenléte. Az újmédia színterein megjelenő közlések segítik az egyéni feldolgozást.

E blogok és a szociális média felületén rendszeresen megjelentetett tartalmak alapos, valamint a minta teljességének - ilyen aspektusból történő elemzésére törekvő vizsgálatát követően kijelenthető, hogy a keresőszóra indított szúkítéssel szinte csak olyan blogokat és facebook-bejegyzéseket lehet találni, amelyek tartalma kórházi kezelésekre, betegség-előrehaladásra vonatkozik. A fentieket összefoglalva igazolódni látszik a korábbi hipotézis: az újmédia színtereit az internethasználók közül sokan felhasználják naplóírás és információmegosztás közzétételére, s tetten érhető a fáma-elbeszélők² (Jancsák, 2013) jelenléte is. Ha a blogíró esetében az egészséges állapot elvesztését, vagy a potenciálisan felsejlő halál képét, mint egyfajta kiterjesztett anticipációs gyászfolyamatot értelmezem, akkor a kiterjesztett fogalomhasználattal (Kiss, 2003) megjelenhet a blogíró betegnél az érzelmek tagadása vagy kifejezési képtelensége. Tapasztalható továbbá túlzott aktivitás és ismétlődő közléskényszer is.

Kutatásom során megismerkedtem például egy 16 esztendős bloggerrel, akinek osztály- és iskolatársai mellett csapattársai, tanárai, szüleinek barátai kétszáznál is több szöveges üzenetben és e-mail-ben érdeklődtek hogyléte felől az első kórházban töltött héten. Adatközlőm az otthonában felvett mélyinterjú során rávilágított arra: ha minden üzenetre informatív és egyedi választ küldött volna, ideje sem lett volna a kezeléseken részt venni, gyógyulására koncentrálni. A személyes üzenettartalmak előállítása helyett kezd ilyen esetben naplót vezetni a beteg. Találkoztam olyan, gyógyulás útjára lépett bloggerrel, aki blogot írt betegségének első napjaitól egészen a hároméves kontrollvizsgálat lezárulásáig. Sajnos látókörömbe került olyan be nem fejezett szöveg is, amely egy napon váratlanul megszakadt, mert az írója elhunyt. Ebben az esetben javaslom a „haldoklási napló" terminus használatát. Mert, ahogy Babits Mihályt a beszédprodukcióban gátolta súlyos betegsége, úgy ismerőseik elvárásairól, egyfajta kommunikációs kényszerhelyzetről vallanak a környezetükből betegségük miatt kiszakított bloggerek is. A kutatáshoz felvett mélyinterjúban elhangzottak szerint, rendkívül összetett kommunikációs feladat nehezedik a családjától, iskolájától vagy munkahelyétől elszakított betegre.

\footnotetext{
2 Fáma-elbeszélő, azaz mesemondó. Magyar nyelvú szójáték a FaceBook nevével, amely arra utal, hogy a Facebook virtuális terében megosztott érzések nem azonosak a valós (face-to-face) kommunikációban kifejezettekkel, és a virtuális személyiségek közötti kommunikációban a közlés célja és szándéka sok esetben eltér a személyes beszédcselekvésben megjelenő valóságostól. (Jancsák Csaba, szóbeli közlés; SZAB, Szeged, 2015. 05. 12.)
} 
Egy másik adatközlőm első motivációja a naplóírás cselekményében az időstrukturálás volt. Blogbejegyzéseiben részletgazdagon leírta fejfájásainak mind gyakoribbá válását, megnövekedett alvásigényét, majd annak az orvosi közlésnek a befogadását, ami a korosztályában magas előfordulási gyakoriságú rosszindulatú betegségről adott hírt. Tragédiájának „,magából kiírása" lépésról lépésre haladt; hajhullásának szemmel látható jelét, a kemoterápia lépcsőit, és testének a kezelésekre adott reakcióit írta meg blogján. Olvasói között a kezdetekben ismeróseit látta viszont, aztán egyre inkább bóvült a kör: betegtársainak hozzátartozói, később pedig ismeretlenek is követni kezdték a blogger olykor képekkel illusztrált betegségnaplóját, rendszeres olvasói és követői lettek a szociális média felületén is. Naplóstílusa (ami értelmezhető veszteségközzétételnek is, ugyanis az egészsége elvesztésének traumája a blog vezérmotívuma) a szöveg elején még magán viseli a hárítás, a tiltakozás és a válaszok keresésének jegyeit; az étvágytalanság és hajhullás szomorú tapasztalata a régi külső utáni vággyal jelenik meg. A steril szobába kerüléssel az interperszonális kapcsolatok drasztikus megszúnése, az ingerszegény környezet fájó élménye jelenik meg a bejegyzésekben. Egy ponton azonban jövőbe tekintő, hajának elvesztését és testének radikális megváltozását is elfogadó hölgy sorait találjuk. A hiánytapasztalatok és veszteségélmények felszínre törése helyett a reményteli jövőbe tekintés lett a szöveg sajátja. A bekezdés zárómondatát a bloggertől idézem: "Magam miatt kezdtem írni, utána a barátaimnak, most meg idegenek is követnek. Majd én is újraolvasom egyszer."

A blogok szövegvilágát mélyebb struktúrában elemezve megállapítom, hogy a bloggerek - a Polcz Alaine-féle gyászkategorizáció (Polcz, 1989) kiterjesztett értelmezése szerint a "sóvárgás, keresés”, a "talajvesztettség (szétesés, regresszió, káosz)" fázisban lehetnek, ugyanis a "Hogyan történhetett ez?", "Miért pont én?", „Nem tudom, hogy lesz ezután!" mondatok jelentős túlsúlyban vannak. Az elemzett blogbejegyzésekben gyakoriak a hiányos, grammatikailag nem teljes értékú mondatok, és megjelentek az érzelmek kifejezésére szolgáló grafikus jelek (emotikonok vagy smiley-k; Laczházi, 2004).

\section{7. Összegzés}

Álláspontom szerint az újmédia felületén közzétett egyéni veszteséget a blogíró betegek nem egyéni, azaz terápiás szövegalkotási céllal teszik közzé, hanem információadási gesztussal. Követőiknek és olvasóiknak halmaza heterogén, az olvasók szocioökonómiai státusza és blogoldalra látogatásának motivációja sokszor felfedhetetlen. Ám a visszacsatolások (reagálások, kommentek, a különböző emotikonokkal való válaszadás) révén az egyén betegségélménye a közösségi együttérzést és támogatást, a fájdalomban és 
veszteségben való „osztozást” segíti. A kutatásban részt vevő adatközlők rendkívül intim információkat osztottak meg velem, amelyeket a helsinki és tokiói egyezményeknek való megfelelés miatt nem emelhetek be e tanulmányba. Ám annyit mégis rögzíteni kívánok, hogy az olvasó és a blogger közötti virtuális kapocs személyközivé is válhat. Igaz és mély barátságok, sorstársi támogatás, olykor szerelmek születhetnek.

Úgy vélem, e közzétételi formával oldható a szorongás, a betegség megnevezésével, az arról való beszéddel kapcsolatos kommunikációs gócok is megszúnhetnek. Ha a felhasználó „már elmondta, közzétette” fájdalmát, akkor a sokszori retraumatizáló újranarrálás helyét átveheti a támogató beszélgetés és a jövőbe tekintó pozitív attitúd. Az újmédia színterein megjelenő közlések tehát segíthetik az egyéni feldolgozást.

\section{Irodalom}

Aczél, P., Andok, M., \& Bokor, T. (2015). Müveljük a médiát! Budapest: Wolters Kluwer Kft. Ajjan, H., Hartshorne, R. (2008). Investigating faculty decisions to adopt Web 2.0 technologies: Theory and empirical tests. The Internet and Higher Education, 11(2), 71-80.

Barthes, R. (1996). A szöveg öröme. Irodalomelméleti írások. Budapest: Osiris

Berán, E., \& Unoka, Zs. (2012). The attention regulating role of shifting narrative perspective in therapeutic discourse: The analysis of two psychotherapeutic sessions. Magyar Pszichológiai Szemle, 67(3), 467-490.

Berners-Lee, T., Hall, W., Hendler, J., Shadbolt, N., \& Weitzner, D. (2006). Creating a science of the Web. Science, 313(5788), 769-771.

Buda, B. (1988). A közvetlen emberi kommunikáció szabályszerüségei. Budapest: Animula Kiadó

Buzzi, M. C., Buzzi, M., \& Leporini, B. (2010). Accessibility and usability of web content and applications. In F.V. Cipolla-Ficarra (Ed.), Quality and Communicability for Interactive Hypermedia Systems: Concepts and Practices for Design (64-90). Hershey, PA: Information Science Reference.

Carel, H. (2013). Illness, phenomenology, and philosophical method. Theoretical Medicine and Bioethics, 34, 345-357.

Eckermann, J.P. (1989). Beszélgetések Goethével. Budapest: Magyar Helikon Könyvkiadó

Esterházy, P. (2016). Hasnyálmirigynapló. Budapest: Magvető

Hamkins, S. (2013). The art of narrative psychiatry: stories of strength and meaning. Oxford: Oxford University Press

Jancsák, Cs. (2013). Ifjúsági korosztályok korszakváltásban. Budapest: Új Mandátum Könyvkiadó

Jenkins, H., Ford, S., \& Green, J. (2013). Spreadable media: Creating value and meaning in a networked culture. New York: New York University Press

Kiss, K. (2003). Depression and grief-reaction. Symptomatological comparison especially of suicidal symptoms. PhD Thesis. Budapest: Semmelweis University

Laczházi, Gy. (2004). Az emotikonok és a koraújkor érzelemkifejező technikái. Letöltve: 2018. 03.06-án: http:// magyar-irodalom.elte.hu/arianna/irat/emoticon.html

László, J. (2005). A történetek tudománya. Bevezetés a narratív pszichológiába. Budapest: Új Mandátum Kiadó 
Lewis, B. (2011). Narrative psychiatry: how stories can shape clinical practice. Baltimore: John's Hopkins University Press

McQuail, D. (2003). A tömegkommunikáció elmélete. Budapest: Osiris

Pászka, I. (2007). A szövegalapú „társadalomtudomány” lehetőségei. Bölcsészműhely, 1, 97-113.

Pászka, I. (2007). Narratív történetformák. Szeged: Belvedere Maridionale

Pilling, J. (2008). Rossz hírek közlése. In: J. Pilling (szerk.), Orvosi kommunikáció (306-334).

Budapest: Medicina Könyvkiadó

Polcz, A. (1989). A halál iskolája. Budapest: Magvető Kiadó

Pólya, T. (2007). Identitás az elbeszélésben. Szociális identitás és narratív perspektíva. Budapest: Új Mandátum Kiadó

Szépe, O., \& Ferdinandy, N. (2010). Intimitás és nyilvánosság. A gyász- és halál-témájú blogok néhány sajátosságáról. Kharón Thanatológiai Szemle, 14(1), 47-58.

Szúts, Z. (2011). Torlódott galaxisok. A nyomtatott szöveg és a világháló korának párhuzamai. Egyenlítö, 9(7-8), 60-66.

Tátrai, Sz. (2000). Az elbeszélő „én” nyelvi jelöltsége. Magyar Nyelvőr, 124(2), 226-238.

Varga, Z. (2014). Önéletrajzi tér és talált szöveg: Babits Mihály Beszélgetöfüzetei. Literatura, 40(1), 60-76.

Zelena, A. (2017a). Veszteségkommunikáció az újmédia színterein. Médiakutató, 18(1-2), 139-149.

Zelena, A. (2017b). Van-e helye a gyászjelentéseknek a közösségi portálokon? Kharón Thanatológiai Szemle, 20(1), 1-10.

\section{Köszönetnyilvánítás}

A tanulmány alapját képező előadás az I. Ártó-Védő Társadalom Konferencián (2017. június 8-9.) hangzott el. A szöveg gondozásáért köszönettel tartozom a Mentálhigiéné és Pszichoszomatika folyóirat 19. évfolyama 3. számának vendégszerkesztőinek, dr. Susánszky Évának és dr. Szántó Zsuzsának.

\section{Nyilatkozat érdekütközésról}

A szerző ezúton kijelenti, hogy esetében nem állnak fenn érdekütközések. 


\title{
Diary of illness in the new media
}

\author{
ZELENA, ANDRÁS
}

Theoretical Background: There is growing emphasis on the announcement and sharing of various life events on the platforms of new media (Web 2.0). Such platforms can be social media sites, file or video sharing pages or blogs. My research paper focuses on texts documenting illness and treatment, and special attention is given to the presentation of the various possibilities offered by narratology and communal processing. In the analysis of this complex topic I am relying on implications of the interdisciplinary theories of psychology and scientific study of communication. Objective: I am looking at ways in which traditional rituals of communication and loss announcement are interconnected with diaries of illness shared on new media (especially social media) platforms. The research aims to find out which elements and aspects of the diaries of illness find their way into the framework of new media, what the interpersonal relationships are like and what supportive gestures a person, who shares his diary of illness in the form of a blog, can expect. Method: In-depth interviews and dynamic non-directed interviews were conducted with bloggers treated in hospital $(N=17)$, and structured interviews were conducted with informants in custodial care, during rehabilitation period $(N$ sum $=27)$. The socioeconomic status of informants: proportionate distribution of men and women (14 women and 13 men), with informants representing each level of education from 8 completed classes to MA/MSC, their place of living being mostly the capital or its area. The interviewees had all been treated for oncological diseases. I am also studying the structure of diary texts chosen for detailed analysis by means of "simple random sampling", focusing on their grammatical and semantic features. Results: I am presenting the possible supportive gestures that come in response to the act of sharing on new media platforms, and I am also presenting the possibilities of therapeutic writing, placing them in the context of the work of international theoreticians. By conducting in-depth interviews, dynamic non-directed interviews and structured interviews $(n=27)$ I found that by means of feedback (reactions, comments and replies with different emoticons) the experience of illness becomes communal experience, and that public compassion and support is probable. Messages shared on new media platforms facilitate individual processing. Conclusion: The synthesis and interpretation of the processes presented in the paper offer possibility for further comparison in the context of relevant theories of psychology and the scientific study of communication, and in the light of the new Hungarian and international research results. Writing a diary with therapeutic purpose benefits the blogger. This process would be worth further analysis.

Keywords: loss announcement, diary of illness, new media, web 2.0

A cikk a Creative Commons Attribution 4.0 International License (https:/ / creativecommons.org/ licenses/by/4.0/) feltételei szerint publikált Open Access közlemény, amelynek szellemében a cikk bármilyen médiumban szabadon felhasználható, megosztható és újraközölhető, feltéve, hogy az eredeti szerző és a közlés helye, illetve a CC License linkje és az esetlegesen végrehajtott módosítások feltüntetésre kerülnek. (SID_1) 